\title{
Evaluation of periopathogenic bacteria of peri-implantitis using real-time PCR in Koreans: pilot study
}

\author{
Mun-Young Lee 1 , Eun-Young Kwon², Hyun-Joo Kim¹, Ju-Youn Lee', Ji-Young Joo* \\ ${ }^{1}$ Department of Periodontology, School of Dentistry and Dental Research Institute, Pusan National University, Yangsan, \\ Republic of Korea \\ ${ }^{2}$ Dental Clinic Center, Pusan National University Hospital, Pusan, Republic of Korea
}

Purpose: We performed quantitative and qualitative analysis of typical periodontal bacteria using real time PCR method to investigate the microbiological difference according to the severity of peri-implant disease in Koreans. Materials and Methods: Total of 60 implants were divided into three groups (healthy group, peri-implant mucositis group, peri-implantitis group) through periapical radiographs and clinical indices. The evaluated clinical parameters were pocket depth, plaque index, suppuration and bleeding on probing. Using a sterilized curette instrument, microbial samples were collected from the subgingival plaque and real-time PCR was performed on five periodontal bacteria. The relative expression levels of microorganisms were compared by comparative deltaCT method. Results: The relative expression levels of $E$. corrodens and $T$. denticola were significantly higher in the peri-implantitis group $(P<0.017)$. On the other hand, the relative expression level of $F$. nucleatum and $P$. gingivalis was relatively high in the healthy implant group regardless of the severity of disease. $P$. intermedia was significantly lower in the healthy implant group $(P<0.017)$. Conclusion: Periodontal bacteria were detected in Koreans with peri-implant diseases, but there was no microbiological distribution similar to periodontitis. (J Dent Rehabil Appl Sci 2018;34(3):186-95)

Key words: peri-implantitis; microbiota; Koreans; pilot study

\begin{abstract}
서론
임플란트를 이용한 상실치아 수복치료법은 높은 성공 율이 보고됨으로써 환자와 치과의사 모두에게 큰 장점을 제공하며 무치악 부위 보철 치료의 통상적인 치료법으로 받아들여 지고 있다. ${ }^{1}$ 임플란트 치료가 대중적으로 보급 됨에 따라 그와 관련된 합병증도 떠오르는 문제가 되었 는데, 대표적인 합병증이 임플란트 주위 질환이다. ${ }^{2}$ 임플 란트 주위염 같은 임플란트 주위 질환은 후기 임플란트 실패의 주요한 원인중의 하나로 여겨지고 있다. ${ }^{3}$ 임플란 트 주위 질환은 주로 임상적 검사 및 방사선학적 평가를

*Correspondence to: Ji-Young Joo

Assistant Professor, Department of Periodontology, School of Dentistry, Pusan National University, Dental Research Institute, 20 Geumo-ro, Beomeo-ri, Mulgeum-eup, Yangsan, 50612, Republic of Korea

Tel: +82-55-360-5203, Fax: 82-55-360-5194, E-mail: joojy@pusan.ac.kr

Received: July 9, 2018/Last Revision: July 26, 2018/Accepted: August 6, 2018
\end{abstract}

기반으로 하여 진단된다. 임플란트 주위염은 임플란트를 둘러싸고 있는 치주조직의 탐침 시 출혈, 삼출물을 포함 하는 염증성 징후와 함께 지지 변연골 소실이 $2 \mathrm{~mm}$ 이상 을 보이는 염증성 상태로 정의된다. ${ }^{47}$ 임플란트 주위 점 막염은 변연골 소실을 동반하지 않는 임플란트 주위 점 막의 염증 상태를 말한다. ${ }^{7.9}$

치주염의 병력, 흡연 및 조절되지 않는 당뇨 등의 전신 질환은 임플란트 주위질환과 관련된 중요한 위험요소들 이나, ${ }^{10,11}$ 또 다른 병인 중 하나로 박테리아 biofilm의 중 요성 또한 광범위하게 연구되었고 치은염 및 치주염과 마찬가지로, 임플란트 주위 점막염 및 임플란트 주위염 
도 미생물 감염으로 시작된다고 알려져 있다. ${ }^{12-14}$ 몇몇 연 구에서 건강한 임플란트군과 임플란트 주위 질환에 이환 된 임플란트 군에서의 치주낭 내 미생물 구성의 차이를 비교하였다. ${ }^{15,16}$ 두 군간에서의 미생물 구성의 차이에 대 한 것은 논란의 여지가 있는 결과를 보여주었다. 일부 연 구에서 임플란트 주위에 치주병인균이 발견되더라도, 건 강한 임플란트와 임플란트 주위 질환 사이의 발생 빈도 는 차이가 없음을 보여주었다. ${ }^{17-19}$ 반면 최근의 한 체계적 인 검토에서는 질환이 있는 임플란트와 건강한 임플란트 에서의 치은 열구 내 미생물 조성이 상당한 차이가 나타 남을 보여주었다. ${ }^{20}$

지리적 및 인종과 관련하여 치주염의 유병율과 미생물 구성의 차이가 있다는 사실은 이미 많은 연구들에서 보 고 되었다. ${ }^{21-24}$ 인구표본에 따르면, 치주염은 특정한 인종 에서 유병률이 높기 때문에 특정한 인종에서의 임플란트 주위염의 유병률에도 영향을 줄 수 있다. ${ }^{25}$ 최근의 메타 분석에 따르면, 서로 다른 인종에서 임플란트 주위염의 유병률은 차이가 난다. ${ }^{26}$ 이 메타분석에서 임플란트 주위 질환의 유병률은 인종에 따라 임플란트 주위 점막염은 $19 \%$ 에서 $65 \%$ 로 나타났으며 임플란트 주위염은 $1 \%$ 에 서 $47 \%$ 로 나타났다. 이들 인구표본의 다양한 지리적 및 임상적 환경이 임플란트 주위염 유병률의 인종에 따른 차이의 원인으로 생각된다. ${ }^{26,27}$ 최근 한국인에서 치주염 병력이 있었던 환자에서 임플란트 주위염의 유병률에 대 한 단면연구가 있었다. ${ }^{28}$ 그러나 한국인에서 임플란트 주 위염의 미생물 분석에 대한 보고는 없었다.

따라서 본 연구에서는 한국인에서 임상적 기준에 의해 분류된 임플란트 주위 질환의 심도에 따른 미생물학적 차이를 알아보기 위해 real time Polymerase Chain Reaction (real time PCR)법을 이용하여 대표적 치주세균을 정량적 그리고 정성적 분석을 시행하였다.

\section{연구 재료 및 방법}

\section{1. 연구대상}

본 연구는 2017년 3월에서 2018년 3월 사이에 부산대 학교 치과병원 치주과에 내원한 환자 중 만 20세에서 82 세까지의 성인 남녀를 대상으로 다음과 같은 기준을 만 족하는 환자에 한하여 시행되었다.

- 임플란트 식립 후 보철물을 사용한지 1년이 경과한 환자
- 임신, 제 1 형 당뇨병 등 조절되지 않는 전신질환을 가 지지 않은 전신적으로 건강한 환자

- 최근 6주 이내 항생제 처방을 받지 않은 환자

- 최근 6개월 이내 임플란트 주변 치주 처치를 받지 않 은 환자

연구 대상자들은 치근단 방사선 사진 촬영 및 임상검 사를 통해 2012년 Froum의 분류에 따라 ${ }^{29}$ 건강군, 임플 란트 주위 점막염군, 임플란트 주위염군의 세군으로 나 뉘어 졌으며 각 군당 20 명씩 총 60 명의 환자가 포함되었 다. 골소실이 없고, 탐침 시 출혈이나 화농이 관찰되지 않 으면 건강한 임플란트로, 골소실은 없으나, 탐침시 출혈 이나 화농이 있으면 임플란트 주위 점막염으로 분류하였 다. 임플란트 주위염은 골소실이 관찰되며 $4 \mathrm{~mm}$ 이상의 치주낭 깊이, 탐침 시 출혈이나 화농이 동반되는 경우로 진단하였다. 연구에 참여한 환자들은 실험에 대한 자세 한 설명을 들었고 자발적으로 동의서에 서명하였다. 임 상 실험 프로토콜은 부산대학교 치과병원 생명윤리심의 위원회의 승인(PNUDH-2017-008)을 받았다.

\section{2. 연구방법}

1) 임상검사

다음의 임상지표들은 각 환자 내에서 다수의 임플란트 를 가지는 경우 가장 질환이 심한 한 개의 임플란트만 선 택하여 검사하였다.

- 치주낭 깊이(PD): 치주 탐침기를 이용하여 유리 치은 변연으로부터 치주낭 기저부까지의 깊이를 측정함.

- 치태 지수(PI): 구강 청결도를 의미하는 지수, 치태의 두께에 따라 치태가 부착되어 있지 않은 상태는 ' 0 ', 치아와 유리치은 변연에 부착된 치태로서 치주 탐침 기로 치면을 긁어보아 확인할 수 없는 엷은 상태는 ' 1 ', 치은낭과 치은변연을 따라 육안으로 확인될 수 있을 정도로 과량의 치태가 부착되어 있고 치간 사이 에 치태가 없는 상태는 ' 2 ', 치은변연에 많은 양의 치 태가 침착되어 있고 치간 사이에도 치태가 채워져 있 는 상태는 '3'으로 구분하여 표기함.

- 탐침시 출혈(BOP): 치은 염증을 평가하는 지수로 치 주 탐침 후 30 초 이내의 출혈을 관찰하여 출혈의 발 생 유무를 표기함.

- 화농성 삼출물(Sup): 치은 염증을 평가하는 지수로 치은 열구 주변으로 화농성 삼출물의 배출 유무를 표 기함. 
치태지수는 치아 당 4 부위(근심 협측, 협측 정중부, 원 심 협측, 구개/설측)에서 측정되었고 나머지 각 임상지표 들은 치아 당 6 부위(근심 협측, 협측 정중부, 원심 협측, 근심 설측, 설측 정중부, 원심 설측)에서 측정되었다. 모 든 측정은 치주 탐침기(PGF-W, 오성제조사, 광명시, 경 기도, 한국)를 사용하여 $1 \mathrm{~mm}$ 단위로 반올림하여 표시 하였다. 임상지표 측정은 한 명의 숙달된 술자에 의해 시 행되었으며 내원 당일 1회 검사로 마무리되었다.

2) 미생물 샘플 채취

멸균된 거즈를 이용하여 치은연상 치태를 제거하고 멸 균 거즈로 선택된 임플란트를 타액과 혈액으로부터 격리 한 후, 치주낭 하방으로 멸균된 curette 기구를 삽입하여 치은연하 치태를 채취하였다. 채득된 샘플을 $500 \mathrm{ul} \mathrm{ster-}$ ile $0.225 \%$ Ringer's solution이 담겨진 $1.5 \mathrm{ml}$ 튜브에 옮 기고 이 후 분석이 시행되기까지 $-20^{\circ} \mathrm{C}$ 에 저장되었다.

3) 미생물학적 평가

치은연하 샘플은 Eikenella corrodens, Fusobacterium nucleatum spp., Porphyromonas gingivalis, Prevotella intermedia, Treponema denticola와 총 세균수를 함께 탐지하고 이를 정 량하기 위해 quantitative real-time PCR로 분석되었다. ${ }^{30}$ 분석을 위해 이용된 PCR primer sequence와 product size는 Table 1과 같다.

$-20^{\circ} \mathrm{C}$ 에 저장된 샘플은 $200 \mathrm{ul}$ 의 PBS용액이 담긴 1.5 $\mathrm{ml}$ 원심분리용 튜브로 옮겨져 trizol 방법으로 RNA를 추 출하였다. RNA 추출은 다음 과정과 같다. 샘플은 PBS buffer를 제거한 후 200 ul trizol과 40 ul의 chloroform 을 첨가하여 완전하게 균질화 될 때까지 강하게 혼합하 였다. 이 후 원심 분리하여 상층부를 새로운 $1.5 \mathrm{ml}$ 튜브 로 옮기고, $500 \mathrm{ul}$ 의 Isopropanol을 첨가한 후 $4^{\circ} \mathrm{C}$ 에서 15 분간 원심 분리하였다. Isopropanol을 pellet에서 조심 스럽게 제거하고, 위 과정을 반복한 후 pellet을 15 분간 상온에서 건조시켰다. 건조된 RNA pellet을 $20 \mathrm{ul}$ RNase free water에 용해시키고 10 분간 $60^{\circ} \mathrm{C}$ heat block 시행하 여 RNA를 추출하였다. 추출한 RNA 농도를 Microplate reader (Synergy HTX Multi-Mode Reader, BioTek, Winooski, USA)로 확인 후 $500 \mathrm{ng}$ 으로 정량하여 Dyne Reverse Transcriptase (DyneBIO, Seoul, Korea)로 $\mathrm{cDNA}$ 를 합성하였다.

Real-timp PCR은 ABI 7500 Fast $^{\circledR}$ (Applied Biosystems, Foster City, USA)를 사용하여 시행하였다. PCR 반응액은 Dyne qPCR 2X preMIX (SYBR Green with low ROX ${ }^{\circledR}$ DyneBIO, Seoul, Korea) 10 ul에 initiator로 각각 Template DNA 1 ul, primer 1 ul씩 넣고 Diethyl Pyrocarbonate로 총 $20 \mathrm{ul}$ 가 되게 하였고, 최초 변성을 위해 $95^{\circ} \mathrm{C}$ 에서 10 분간 이후 55 번의 중합효소 연쇄반응 cycle은 $95^{\circ} \mathrm{C}$ 에서 15 초, $58^{\circ} \mathrm{C}$ 에서 1 분, $72^{\circ} \mathrm{C}$ 에서 1 분간 시행하여 증폭하였다. 이 때 Dyne qPCR 2X preMIX은 PCR로 합성된 double-stranded DNA에 결합하여 형광 을 나타내며, 반응이 진행되면서 발생하는 형광신호를 감지하여 유전자의 증폭양상을 분석함으로써, 증폭 산물 의 생성량을 측정하였다.

Table 1. PCR primer sequence and Product size

\begin{tabular}{|c|c|c|}
\hline Bacteria & Oligonucleotide sequence & Product size $(\mathrm{bp})$ \\
\hline \multirow{2}{*}{ Total bacteria } & F: 5'-CGCTAGTAATCGTGGATCAGAATG-3' & \multirow{2}{*}{69} \\
\hline & R: 5'-TGTGACGGGCGGTGTGTA-3' & \\
\hline \multirow{2}{*}{ E. corrodens } & F: 5'-AGGCGACGAAGGACGTGTAA-3' & \multirow{2}{*}{69} \\
\hline & R: 5'-ATCACCGGATCAAAGCTCTATTG-3' & \\
\hline \multirow{2}{*}{ F. nucleatum } & F: 5'-TGCGATAAGCCTAGATAAGT'TGCA-3' & \multirow{2}{*}{70} \\
\hline & R: 5'-CTTAATAGAT'TGCTCCATTCGGAAA-3' & \\
\hline \multirow{2}{*}{ P. gingivalis } & F: 5'-TGGT'T'TCATGCAGCTTCT'TT-3' & \multirow{2}{*}{126} \\
\hline & R: 5'-TCGGCACCTTCGTAATTCT'T-3' & \\
\hline \multirow{2}{*}{ P. intermedia } & F: 5'-GACCCGAACGCAAAATACAT-3' & \multirow{2}{*}{129} \\
\hline & R: 5'-AGGGCGAAAAGAACGTTAGG-3' & \\
\hline \multirow{2}{*}{ T. denticola } & F: 5'-AGAGCAAGCTCTCCCT'TACCGT-3' & \multirow{2}{*}{105} \\
\hline & R: 5'-TAAGGGCGGCT'TGAAATAATGA-3' & \\
\hline
\end{tabular}

F:forward, R:reverse 


\section{4) 통계분석}

연구대상자의 임상지표 및 미생물학적 상대적 발현 지수 등은 평균과 표준편차로 표시하였다. quantitative real-time PCR 분석을 이용한 세균의 상대적 발현량 분 석은 Pfaffl이 제시한 comparative delta-CT method를 이용하여 계산하였다. ${ }^{31}$ 각 그룹당 20 개 표본으로 임상 지표 및 상대적 발현량은 Kruskal-Wallis tests를 통해 분 석되었고, Mann-Whitney Test를 통해 사후 검정되었다. 사후 검정의 유의수준은 Bonferroni's method에 따라 $1.7 \%(P<0.017)$ 로 설정하였다. 모든 통계 분석은 SPSS 24.0버전 (IBM SPSS Inc., Chicago, USA)을 이용하였다.

\section{결과}

\section{1. 임상적 평가}

본 연구에 포함된 임플란트는 건강한 임플란트 20개, 임플란트 주위 점막염 20개, 임플란트 주위염 20개로 총 60 개의 임플란트가 포함되었다. 연구대상자들의 인구통 계학적 데이터 및 샘플을 채취한 임플란트의 임상지표 는 Table 2 와 Table 3 에 각각 나타냈다. 평균 치주낭 깊이 는 건강한 임플란트 $3.52 \pm 0.85 \mathrm{~mm}$, 임플란트 주위 점
막염 $4.64 \pm 1.65 \mathrm{~mm}$, 임플란트 주위염 $6.83 \pm 2.36 \mathrm{~mm}$ 로 임플란트 주위 질환이 더 진행될수록 유의하게 증가 하였다. 평균 치태 지수는 각 그룹당 $0.20 \pm 0.25 \%, 0.64$ $\pm 0.52 \%, 0.88 \pm 0.44 \%$ 로 마찬가지로 질환의 심도에 따 라 증가하였으나 임플란트 주위 점막염 그룹과 임플란트 주위염 그룹 간의 차이가 유의하지는 않았다. 평균 화농 성 삼출물은 건강한 임플란트 그룹에서는 관찰되지 않았 고, 임플란트 주위 점막염 그룹에서 $0.85 \pm 0.37$, 임플란 트 주위염 그룹에서 $0.80 \pm 0.41$ 빈도로 관찰되었으며 질 환의 심도와는 연관성을 보이지 않았다.

\section{2. 미생물학적 평가}

각 그룹에서의 미생물학적 상대적 발현량은 Table 4에 나타냈다. 총 세균수는 건강한 임플란트 그룹에서 가장 높게 나타났으나 세 그룹에서의 유의한 차이는 나타나지 않았다. E. corrodens의 상대적 발현량은 임플란트 주위 점 막염 그룹, 건강한 임플란트 그룹, 임플란트 주위염 그룹 순으로 증가하였으며 임플란트 주위 점막염 그룹에 비해 임플란트 주위염 그룹에서 유의하게 높게 나타났다 $(P<$ 0.017). 반면 F. nucleatum, P. gingivalis의 상대적 발현량은 질환의 심도와는 관련 없이 건강한 임플란트 그룹에서

Table 2. Demographic characteristics of subjects (mean \pm SD)

\begin{tabular}{lccc}
\hline & Healthy $(\mathrm{n}=20)$ & Peri-implant nucositis $(\mathrm{n}=20)$ & Peri-implantitis $(\mathrm{n}=20)$ \\
\hline Age (years) & $63.05 \pm 8.48$ & $57.85 \pm 10.57$ & $62.25 \pm 9.49$ \\
Females $(\%)$ & $6(30 \%)$ & $7(35 \%)$ & $9(45 \%)$ \\
Males (\%) & $14(70 \%)$ & $13(65 \%)$ & $11(55 \%)$ \\
Loading period (years) & $4.40 \pm 2.71$ & $4.23 \pm 3.30$ & $7.29 \pm 3.24$ \\
Total implant number (number) & $2.85 \pm 2.03$ & $3.25 \pm 2.29$ & $5.25 \pm 3.24$ \\
\hline
\end{tabular}

Table 3. Clinical characteristics of sampling sites (mean \pm SD)

\begin{tabular}{lcccccc}
\hline & $\begin{array}{c}\text { Healthy } \\
(\mathrm{n}=20)\end{array}$ & $\begin{array}{c}\text { Peri-implant nucositis } \\
(\mathrm{n}=20)\end{array}$ & $\begin{array}{c}\text { Peri-implantitis } \\
(\mathrm{n}=20)\end{array}$ & H-PM & $\begin{array}{c}P \\
\text { H-PI }\end{array}$ & PM-PI \\
\hline PD (mm) & $3.25 \pm 0.85$ & $4.64 \pm 1.65$ & $6.83 \pm 2.36$ & $.000^{*}$ & $.000^{*}$ & $.000^{*}$ \\
PI (index) & $0.20 \pm 0.25$ & $0.64 \pm 0.52$ & $0.88 \pm 0.44$ & $.001^{*}$ & $.000^{*}$ & .046 \\
Sup (0/1) & 0.00 & $0.85 \pm 0.37$ & $0.80 \pm 0.41$ & $.000^{*}$ & $.000^{*}$ & 1.000 \\
BOP (0/1) & $0.35 \pm 0.49$ & 1.00 & 1.00 & $.000^{*}$ & $.000^{*}$ & 1.000 \\
\hline
\end{tabular}

H: healthy, PM: peri-implant mucositis, PI: peri-implantitis.

PD: pocket depth, PI: plaque index, Sup: suppuration, BOP: bleeding on probing.

* Statistically significant difference of clinical index among 3 groups using Kruskal-Wallis tests $(P<0.017)$. 
Table 4. Relative expression of bacteria pathogens in target implant subgingival samples from the each group by real-time PCR

\begin{tabular}{lcccccc}
\hline & $\begin{array}{c}\text { Healthy } \\
(\mathrm{n}=20)\end{array}$ & $\begin{array}{c}\text { Peri-implant nucositis } \\
(\mathrm{n}=20)\end{array}$ & $\begin{array}{c}\text { Peri-implantitis } \\
(\mathrm{n}=20)\end{array}$ & $\begin{array}{c}P \\
\text { H-PM }\end{array}$ & $\begin{array}{c}\text { H-PI } \\
\text { PM-PI }\end{array}$ \\
\hline TBC & $26.05 \pm 3.93$ & $24.81 \pm 2.54$ & $24.98 \pm 3.35$ & 0.12 & 0.17 & 0.43 \\
E. corrodens & $38.18 \pm 34.13$ & $19.97 \pm 18.32$ & $49.38 \pm 32.11$ & .096 & .096 & $.002^{*}$ \\
F. nucleatum & $19.18 \pm 8.04$ & $1.63 \pm 2.46$ & $8.88 \pm 7.72$ & $.000^{*}$ & $.000^{*}$ & $.000^{*}$ \\
P. gingivalis & $58.95 \pm 38.12$ & $33.08 \pm 26.35$ & $19.90 \pm 19.94$ & $.002^{*}$ & $.000^{*}$ & $.002^{*}$ \\
P. intermedia & $1.12 \pm 1.87$ & $107.62 \pm 56.27$ & $61.71 \pm 56.23$ & $.000^{*}$ & $.000^{*}$ & $.004^{*}$ \\
T. denticola & $56.51 \pm 40.00$ & $11.52 \pm 8.80$ & $119.21 \pm 113.39$ & $.000^{*}$ & .068 & $.000^{*}$ \\
\hline
\end{tabular}

TBC: tatal bacterial count, $\mathrm{H}$ : healthy-implant, PM: peri-implant mucositis, PI: peri-implantitis.

* Statistically significant difference of bacterial relative expression among 3 groups using Kruskal-Wallis tests $(P<0.017)$.

상대적 발현량이 가장 높게 나타났다. P. intermedia의 상 대적 발현량은 건강한 임플란트 그룹에서 가장 낮았으며 임플란트 주위 점막염 그룹, 임플란트 주위염 그룹에 비 해 유의하게 낮게 나타났다 $(P<0.017) T$. denticola의 상 대적 발현량은 임플란트 주위염 그룹에서 가장 높게 나 타났으며 건강한 임플란트 그룹과 임플란트 주위 점막염 그룹순으로 나타났다.

\section{고찰}

임플란트 주위염의 발병 원인은 다양하며 발병 기전에 관해서는 아직 정립되어 있지 않다. 임플란트 주위염의 미생물 분석 후 치주염 유발 세균이 영향을 끼친다는 결 과를 도출한 외국 사례 논문들은 있으나 이도 샘플수가 그리 많지는 않으며, ${ }^{15-20}$ 임플란트 표면은 치근과 달리 굴 곡이 있고 표면처리가 되어 있으며 치주조직과 부착 방 식에도 치근과는 차이가 있어 아직 연구가 더욱 필요하 다. ${ }^{32}$ 지금까지 알려진 바로 임플란트 주위염의 치료에 있 어 가장 중요한 것은 병적 치주낭 내 항균작용과 오염된 임플란트 표면을 청소하는 것이다. ${ }^{12}$ 효과적인 치료를 위 해서 임플란트 주위 질환의 미생물 분석이 좀 더 이루어 질 필요가 있다. 본 연구에서는 한국인에서 임상적으로 분류된 임플란트 주위 질환의 심도에 따른 미생물학적 차이를 비교해보기 위해 5 가지 치주 원인균을 정량적 및 정석적으로 분석하였다.

미생물 분석 결과, Orange complex에 속하는 F. nucleatum의 상대적 발현량은 임플란트 주위 질환 보다 건강한 임플란트에서 더 높게 나타났다. 반면 Orange complex 에 속하는 또 다른 박테리아인 P. intermedia의 경우에는
임플란트 주위 질환에서 건강한 임플란트 보다 유의하게 높게 나타났다 $(P<0.017)$. Green complex인 E. corrodens 의 경우에 건강한 임플란트에 비해 임플란트 주위염에서 높게 나타났지만 유의하지는 않았고, 임플란트 주위 점 막염에 비해 임플란트 주위염에서 유의하게 높게 나타 났다 $(P<0.017)$. Red complex에 속하는 P. gingivalis, $T$. denticola의 상대적 발현량은 건강한 임플란트 보다 주위 질환이 있는 임플란트에서 상대적 발현량이 높을 것이라 예상되었지만 본 연구의 결과에서는 P. gingivalis의 경우 건강한 임플란트에서 상대적 발현량이 가장 높게 나타났 으며 T. denticola는 임플란트 주위염에서 가장 높게 나타 났다. 각 군의 두 박테리아의 발현량 차이는 유의하지 않 았다.

본 연구에서의 미생물 분석 결과는 임플란트 주위 미생 물 분석에 대한 몇몇의 연구들과 일치하거나 상반된 결 과를 보였다. 건강한 임플란트와 임플란트 주위염의 치 은 연상 및 치은 연하 biofilm의 미생물학적 구성을 분석 한 Shibili 등 ${ }^{33}$ 의 연구에서 치은 연하 미생물 분석 결과에 서 본 연구의 결과와 같이 임플란트 주위염에서 건강한 임플란트 보다 P. intermedia의 상대적 발현량이 더 높게 나타났으나 F. nucleatum은 상반된 결과로 건강한 임플란 트에서 발현량이 더 낮았다. Ebadian 등 ${ }^{34}$ 은 69 명의 이란 인을 대상으로 치주염의 원인균 10 종에 대해 건강한 치 주조직과 건강한 임플란트, 치주염과 임플란트 주위염에 서의 미생물 차이를 정량적, 정석적으로 분석하였다. 이 연구의 결과 중 건강한 임플란트와 임플란트 주위염에서 의 미생물 차이를 비교하였을때 P. intermedia, A. actinomycetemcomitans, T. denticola같은 일부 미생물종에서의 출현 율과 수준에서 두 그룹의 유의한 차이는 보이지 않았으 
며 임플란트 주위염에서는 P. gingivalis가 가장 우세하였 다. Zhuang 등 ${ }^{35}$ 은 22 명의 중국인을 대상으로 질환 정도 에 따른 치아와 임플란트에서 6종의 미생물의 출현율과 수준을 정량적 분석을 통해 비교하였다. 결론적으로 6종 의 미생물은 임플란트의 질환 정도와는 관계없이 출현율 및 수준에서 차이가 유의하지 않았다. Ogata 등 ${ }^{36}$ 은 일본 인에서 임플란트 주위염의 유병율 및 위험 인자를 조사 하였고 연구의 미생물 분석 결과에서 임플란트 주위염이 건강한 임플란트에 비해 P. intermedia, P. gingivalis가 유의 하게 높은 수준으로 관찰되었다.

본 연구 결과에서는 E. Corrodens와 T. denticola가 임플 란트 주위염에서 유의하게 많이 관찰되었다. E. Corrodens 의 경우 Green complex에 속하여 만성 치주염 발생 초 기 단계에 관여하는 것으로 알려져 있다. ${ }^{37}$ T. denticola는 P. gingivalis, T. forsythia와 함께 Red complex를 구성하며 biofilm 발달 단계의 마지막에 나타나 급성 및 만성 치주 염이 진행된 단계에 관여하며, T. denticola는 치주염에서 탐침 시 출혈의 정도와 관련이 있다. ${ }^{38-42}$ 따라서 치주염에 서와 같이 E. Corrodens, T. denticola는 임플란트 주위 질 환에서도 비슷한 역할을 할 것이라 생각된다. Maruyama 등 $^{43}$ 은 임플란트 주위염과 치주염에서의 미생물 구성의 다양성 척도가 비슷한 것을 확인했다. Moore 등 ${ }^{44}$ 은 임상 적으로 건강한 치주 조직에서 E. corrodens의 높은 유병율 을 확인하였다. 이와 유사하게 본 연구에서도 E. corrodens 는 유의하지는 않았지만 임플란트 주위 점막염 그룹에 비해 건강한 임플란트 그룹에서 더 높게 나타났다. 그러 나 임플란트 주위염 그룹에서도 유의하게 높게 관찰되었 다. Martin 등 $^{45}$ 의 연구 결과에서도 T. denticola가 대부분 의 임플란트 주위염 샘플에서 풍부하게 관찰된 점에서 $T$. denticola에 대한 본 연구의 결과와 일치한다.

치주염에서의 질환의 심도에 따른 미생물 분포와는 달 리 임플란트 주위염에서의 미생물 분포는 다른 나라들에 서 시행된 연구 결과와 유사하게 질병의 심도와 관련하 여 치주 세균 분포의 유의한 상관관계를 보여주지 않았 다. ${ }^{21-24,39-42,44,46}$ 그 이유들로 자연치아와는 달리 다양한 임 플란트의 표면처리 방식, 임플란트 지대주 연결 방식, 제 조회사 등과 같은 임플란트 요인이 추가로 있을 수 있고 이에 따라 주변 미생물 부착 및 변연골 소실 결과가 달라 지는 등 치주염보다 더 많은 요인들이 관련하고 있기 때 문이다. ${ }^{47-50}$

\section{결론}

본 연구 결과 E. corrodens, T. denticola의 상대적 발현량 은 임플란트 주위염 그룹에서 유의하게 높게 나타났다. 한국인의 임플란트 주위질환에서 대표적인 치주염 세균 이 검출되었으나 치주염과 유사한 미생물학적 분포를 보 이지는 않았고 질환의 심도와의 관련성도 보이지 않았 다. 특히 P. gingivalis의 경우 임플란트 주위염 그룹에서 건 강한 임플란트 그룹 보다 상대적 발현량이 더 낮게 나타 났으며 이러한 결과는 적은 샘플 수와 다양한 임플란트 제품의 사용으로 인한 한계라 생각된다. 또한 본 연구는 5 종의 제한된 평가 미생물 군으로 한계를 가진다. 더 많 은 수의 환자 샘플과 다양한 미생물을 이용한 추가 연구 가 필요할 것이다.

\section{Acknowledgements}

본 연구는 2016학년도 부산대학교 교내학술연구비(신 임교수연구정착금)에 의한 연구임.

\section{ORCID}

Mun-Young Lee https://orcid.org/0000-0002-1896-7493

Eun-Young Kwon https://orcid.org/0000-0001-95550360

Hyun-Joo Kim https://orcid.org/0000-0001-7553-6289

Ju-Youn Lee https://orcid.org/0000-0002-0772-033X

Ji-Young Joo https://orcid.org/0000-0002-4050-5797

\section{References}

1. Muddugangadhar BC, Amarnath GS, Sonika R, Chheda PS, Garg A. Meta-analysis of failure and survival rate of implant-supported single crowns, fixed partial denture, and implant tooth-supported prostheses. J Int Oral Health 2015;7:11-7.

2. Buser D, Weber HP, Lang NP. Tissue integration of non-submerged implants. 1-year results of a prospective study with 100 ITI hollow-cylinder and hollow-screw implants. Clin Oral Implants Res 1990;1:33-40.

3. Manor Y, Oubaid S, Mardinger O, Chaushu G, Nissan J. Characteristics of early versus late implant 
failure: a retrospective study. J Oral Maxillofac Surg 2009;67:2649-52.

4. Heitz-Mayfield LJ, Mombelli A. The therapy of peri-implantitis: a systematic review. Int J Oral Maxillofac Implants 2014;29 Suppl:325-45.

5. Sanz M, Chapple IL; Working Group 4 of the VIII European Workshop on Periodontology. Clinical research on periimplant diseases: consensus report of working group 4. J Clin Periodontol 2012:39 Suppl 12:202-6.

6. Zitzmann NU, Berglundh T. Definition and prevalence of peri-implant diseases. J Clin Periodontol 2008:35 Suppl 8:286-91.

7. Jovanovic SA. Diagnosis and treatment of periimplant disease. Curr Opin Periodontol 1994;194204.

8. Lang NP, Berglundh T; Working Group 4 of the Seventh European Workshop on Periodontology. Periimplant diseases: where are we now? - Consensus of the Seventh European Workshop on Periodontology. J Clin Periodontol 2011;38 Suppl 11:178-81.

9. Renvert S, Roos-Jansåker AM, Claffey N. Non-surgical treatment of peri-implant mucositis and periimplantitis: a literature review. J Clin Periodontol 2008;35 Suppl 8:305-15.

10. Sousa V, Mardas N, Farias B, Petrie A, Needleman I, Spratt D, Donos N. A systematic review of implant outcomes in treated periodontitis patients. Clin Oral Implants Res 2016;27:787-844.

11. Turri A, Rossetti PH, Canullo L, Grusovin MG, Dahlin C. Prevalence of peri-implantitis in medically compromised patients and smokers: a systematic review. Int J Oral Maxillofac Implants 2016;31:1118.

12. American Academy of Periodontology. Periimplant mucositis and peri-implantitis: a current understanding of their diagnoses and clinical implications. J Periodontol 2013;84:436-43.

13. Heitz-Mayfield LJ, Lang NP. Comparative biology of chronic and aggressive periodontitis vs. periimplantitis. Periodontol 2000 2010;53:167-81.

14. Maruyama N, Maruyama F, Takeuchi Y, Aikawa C, Izumi Y, Nakagawa I. Intraindividual variation in core microbiota in peri-implantitis and periodonti- tis. Sci Rep 2014;4:6602.

15. Pérez-Chaparro PJ, Duarte PM, Shibli JA, Montenegro S, Lacerda Heluy S, Figueiredo LC, Faveri $\mathrm{M}$, Feres $\mathrm{M}$. The current weight of evidence of the microbiologic profile associated with peri-implantitis: a systematic review. J Periodontol 2016;87:1295304.

16. Rakic M, Grusovin MG, Canullo L. The microbiologic profile associated with peri-implantitis in humans: a systematic review. Int J Oral Maxillofac Implants 2016;31:359-68.

17. Ebadian AR, Kadkhodazadeh M, Zarnegarnia P, Dahlén G. Bacterial analysis of peri-implantitis and chronic periodontitis in Iranian subjects. Acta Med Iran 2012;50:486-92.

18. Renvert S, Roos-Jansåker AM, Lindahl C, Renvert $\mathrm{H}$, Rutger Persson G. Infection at titanium implants with or without a clinical diagnosis of inflammation. Clin Oral Implants Res 2007;18:509-16.

19. Casado PL, Otazu IB, Balduino A, de Mello W, Barboza EP, Duarte ME. Identification of periodontal pathogens in healthy periimplant sites. Implant Dent 2011;20:226-35.

20. Pérez-Chaparro PJ, Duarte PM, Shibli JA, Montenegro S, Lacerda Heluy S, Figueiredo LC, Faveri M, Feres M. The Current Weight of Evidence of the Microbiologic Profile Associated With PeriImplantitis: A Systematic Review. J Periodontol 2016;87:1295-304.

21. Ávila-Campos MJ. PCR detection of four periodontapathogens from subgingival clinical samples. Braz J Microbiol 2003;34:81-4.

22. Cortelli JR, Cortelli SC, Jordan S, Haraszthy VI, Zambon JJ. Prevalence of periodontal pathogens in Brazilians with aggressive or chronic periodontitis. J Clin Periodontol 2005;32:860-6.

23. Lopez NJ, Melhado JC, Leighton GX. Occurrence of Actinobacillus actinomycetemcomitans, Porphyromonas gingivalis and Prevotella intermedia in juvenile periodontitis. J Clin Periodontol 1996;23:1015.

24. Ximenez-Fyvie LA, Almaguer-Flores A, JacoboSoto V, Lara-Cordoba M, Sanchez-Vargas LO, Alcantara-Maruri E. Description of the subgingival microbiota of periodontally untreated Mexican 
subjects: chronic periodontitis and periodontal health. J Periodontol 2006;77:460-71.

25. Eke PI, Dye BA, Wei L, Slade GD, ThorntonEvans GO, Borgnakke WS, Taylor GW, Page RC, Beck JD, Genco RJ. Update on prevalence of periodontitis in adults in the United States: NHANES 2009 to 2012. J Periodontol 2015;86:611-22.

26. Derks J, Tomasi C. Peri-implant health and disease. A systematic review of current epidemiology. J Clin Periodontol 2015;42 Suppl 16:S158-71.

27. Salvi GE, Cosgarea R, Sculean A. Prevalence and mechanisms of peri-implant diseases. J Dent Res 2017;96:31-7.

28. Goh MS, Hong EJ, Chang M. Prevalence and risk indicators of peri-implantitis in Korean patients with a history of periodontal disease: a cross-sectional study. J Periodontal Implant Sci 2017;47:24050.

29. Froum SJ, Rosen PS. A proposed classification for peri-implantitis. Int J Periodontics Restorative Dent 2012;32:533-40.

30. Yoshida A, Suzuki N, Nakano Y, Oho T, Kawada M, Koga T. Development of a 5 ' fluorogenic nucleasebased real-time PCR assay for quantitative detection of Actinobacillus actinomycetemcomitans and Porphyromonas gingivalis. J Clin Microbiol 2003;41:863-6.

31. Pfaffl MW. A new mathematical model for relative quantification in real-time RT-PCR. Nucleic Acids Res 2001;29:e45.

32. Berglundh T, Lindhe J, Ericsson I, Marinello CP, Liljenberg B, Thomsen P. The soft tissue barrier at implants and teeth. Ciln Oral implants Res 1991;2:81-90.

33. da Silva ES, Feres M, Figueiredo LC, Shibli JA, Ramiro FS, Faveri M. Microbiological diversity of peri-implantitis biofilm by Sanger sequencing. Clin Oral Implants Res 2014;25:1192-9.

34. Ebadian AR, Kadkhodazadeh M, Zarnegarnia P, Dahlén G. Bacterial analysis of peri-implantitis and chronic periodontitis in Iranian subjects. Acta Med Iran 2012;50:486-92.

35. Zhuang LF, Watt RM, Mattheos N, Si MS, Lai HC, Lang NP. Periodontal and peri-implant microbiota in patients with healthy and inflamed periodontal and peri-implant tissues. Clin Oral Implants Res 2016;27:13-21.

36. Kato A, Imai K, Sato H, Ogata Y. Prevalence of Epstein-Barr virus DNA and Porphyromonas gingivalis in Japanese peri-implantitis patients. BMC Oral Health 2017;17:148.

37. López R, Fernández O, Jara G, Baelum V. Epidemiology of clinical attachment loss in adolescents. J Periodontol 2001;72:1666-74.

38. Holt SC, Ebersole JL. Porphyromonas gingivalis, Treponema denticola, and Tannerella forsythia: the "red complex", a prototype polybacterial pathogenic consortium in periodontitis. Periodontol 2000 2005;38:72-122.

39. Paster BJ, Olsen I, Aas JA, Dewhirst FE. The breadth of bacterial diversity in the human periodontal pocket and other oral sites. Periodontology 2000 2006;42:80-7.

40. Kigure T, Saito A, Seida K, Yamada S, Ishihara K, Okuda K. Distribution of Porphyromonas gingivalis and Treponema denticola in human subgingival plaque at different periodontal pocket depths examined by immunohistochemical methods. J Periodontal Res 1995;30:332-41.

41. Simonson LG, McMahon KT, Childers DW, Morton HE. Bacterial synergy of Treponema denticola and Porphyromonas gingivalis in a multinational population. Oral Microbiol Immunol 1992;7:111-2.

42. Lanza E, Magan-Fernandez A, Bermejo B, de Rojas J, Marfil-Alvarez R, Mesa F. Complementary clinical effects of red complex bacteria on generalized periodontitis in a caucasian population. Oral Dis 2016;22:430-7.

43. Maruyama N, Maruyama F, Takeuchi Y, Aikawa C, Izumi Y, Nakagawa I. Intraindividual variation in core microbiota in peri-implantitis and periodontitis. Sci Rep 2014;4:6602.

44. Moore WE, Holdeman LV, Cato EP, Smibert RM, Burmeister JA, Palcanis KG, Ranney RR. Comparative microbiology of juvenile periodontitis. Infect Immun 1985;48:507-19.

45. Sanz-Martin I, Doolittle-Hall J, Teles RP, Patel M, Belibasakis GN, Hämmerle CHF, Jung RE, Teles FRF. Exploring the microbiome of healthy and diseased peri-implant sites using Illumina sequencing. 
J Clin Periodontol 2017;44:1274-84.

46. Mombelli A, Décaillet F. The characteristics of biofilms in peri-implant disease. J Clin Periodontol 2011;38 Suppl 11:203-13.

47. Mouhyi J, Dohan Ehrenfest DM, Albrektsson T. The peri-implantitis: implant surfaces, microstructure, and physicochemical aspects. Clin Implant Dent Relat Res 2012;14:170-83.

48. Schwarz F, Alcoforado G, Nelson K, Schaer A, Taylor T, Beuer F, Strietzel FP. Impact of implantabutment connection, positioning of the machined collar/microgap, and platform switching on crestal bone level changes. Camlog Foundation Consensus
Report. Clin Oral Implants Res 2014;25:1301-3.

49. Pieri F, Aldini NN, Marchetti C, Corinaldesi G. Influence of implant-abutment interface design on bone and soft tissue levels around immediately placed and restored single-tooth implants: a randomized controlled clinical trial. Int J Oral Maxillofac Implants 2011;26:169-78.

50. Koo KT, Lee EJ, Kim JY, Seol YJ, Han JS, Kim TI, Lee YM, Ku Y, Wikesjö UM, Rhyu IC. The effect of internal versus external abutment connection modes on crestal bone changes around dental implants: a radiographic analysis. J Periodontol 2012;83:1104-9. 


\section{한국인의 임플란트 주위 질환에서 real time PCR법을 이용한 치주세균 평가: pilot study}

이문영', 권은영 ${ }^{2}$, 김현주 ${ }^{1}$, 이주연 ${ }^{1}$, 주지영 ${ }^{1 *}$

${ }^{1}{ }^{ㅂ ㅜ ㅅ ㅏ ㄴ ㄷ ㅐ ㅎ ㅏ ㄱ ㄱ ㅛ ~ ㅊ ㅣ ㅇ ㅢ ㅎ ㅏ ㄱ ㅈ ㅓ ㄴ ㅁ ㅜ ㄴ ㄷ ㅐ ㅎ ㅏ ㄱ ㅇ ㅝ ㄴ ~ ㅊ ㅣ ㅈ ㅜ ㄱ ㅘ ㅎ ㅏ ㄱ ㄱ ㅛ ㅅ ㅣ ㄹ ~}$

${ }^{2}$ 부산대학교병원 치과진료센터

목적: 한국인에서 임플란트 주위 질환의 심도에 따른 미생물학적 차이를 알아보기 위해 real time Polymerase Chain Reaction (real-time PCR)법을 이용하여 5종의 치주세균의 정량적, 정성적 분석을 시행하였다.

연구 재료 및 방법: 임플란트가 식립된 총 60 명의 환자를 치근단 방사선 사진 및 임상지수 검사를 통해 3 군(건강군, 임플 란트 주위 점막염군, 임플란트 주위염군)으로 나누었다. 멸균된 curette기구를 이용해 치은연하에서 미생물 샘플을 채취 한 후 치주세균 5종에 관해 real time PCR을 시행하였고 comparative delta-CT method를 이용하여 분석한 후 미생물의 상대적 발현량을 비교하였다.

결과: Eikenella corrodens, Treponema denticola의 상대적 발현량은 임플란트 주위염 그룹에서 유의하게 높게 나타났다 $(P<$ 0.017). 반면 Fusobacterium nucleatum, Porphyromonas gingivalis의 상대적 발현량은 질환의 심도와는 관련 없이 건강한 임플란 트 그룹에서 가장 높게 나타났다. Prevotella intermedia의 상대적 발현량은 건강한 임플란트 그룹에서 유의하게 낮게 나타 났다 $(P<0.017)$.

결론: 한국인의 임플란트 주위질환에서 대표적인 치주염 세균이 검출되었으나 치주염과 유사한 미생물학적 분포를 보이 지는 않았다.

(구강회복응용과학지 2018;34(3): 186-95)

주요어: 임플란트 주위염; 미생물; 한국인; 예비연구

*교신저자: 주지영

(50612)경상남도 양산시 물금읍 범어리 금오로 20 부산대학교 치의학전문대학원 치주과학교실

Tel: 055-360-5203 | Fax: 055-360-5194 | E-mail: joojy@pusan.ac. kr

접수일: 2018년 7월 9일 | 수정일: 2018년 7월 26일 | 채택일: 2018년 8월 6일 